\title{
A review on Sandhigatavata and its Management Principles
}

\author{
Review Article
}

\section{Nagesh Gandagi $^{*}$, Shubhangi Patil ${ }^{2}$}

1. Reader, Dept. of Kayachikitsa, 2. H.O.D. \& Reader, Dept. of Roga Nidana, Ahalia Ayurveda Medical College and Hospital, Palakkad - 678557, Kerala.

\begin{abstract}
In the Ayurvedic classics the aetiopathogenesis and symptomatology of Sandhigata vata is described in concise form. Clinically the description of Sandhigata vata explained in the classical texts is similar to the condition osteoarthritis in modern science. Sandhigatavata is described under Vatavyadhi in all the Samhitas and Sangraha Granthas. In Vriddhavastha, all Dhatus undergo Kshaya, Thus leading to Vataprakopa and making individual prone to many diseases. Among them Sandhigatavata stands top in the list. Having the symptoms like pain, swelling, crepitus, and restricted joint movements. Ayurveda highlighted degenerative diseases under the concepts like "Dhatu saithilyam" and "Dhatu kshayam". Sandhigata Vata is one of such disease, which needs a specific target of therapeutic intervention to check or slow down the process of "Dhatu kshaya" and to pacify Vata. Sandhigatavata may be correlated with degenerative joint disease or Osteoarthritis, which in turn cripples the patient to the maximum, extends and reduces the total working capacity of the person. It limits everyday activities such as walking, dressing, bathing etc., thus making individual handicapped.
\end{abstract}

Key words: Ayurveda drugs, Jaanusandhigata vata, Osteoarthritis, Vatavyadhi

\section{Introduction}

In Ayurveda, the disease Sandhigatavata is described under Vatavyadhi in all the Samhitas and Sangraha Granthas. It is mentioned to have the clinical features like swelling in the joints and pain during the joint movements. (3-Anonymous, Caraka Samhita e-book, CCRAS, New Delhi, 2010, Cikitsa sthana, Vatavyadhi Prakarana). It is said to be caused by the

*Corresponding Author:

\section{Nagesh Gandagi}

Reader,

Department of Kayachikitsa,

Ahalia Ayurveda Medical College and

Hospital, Palakkad - 678557, Kerala.

Mobile No. +91- 9526160477,

E-mail-drnagsvgm@ rediffmail.com excessive intake of vata vrudhi kara ahara like katu, tikta and kashaya rasa pradhana dravya and ativyayama (excessive strain or stress to the joints) or abhighata (injuries).

The disease is comparable with osteoarthritis. Osteoarthritis is a degenerative joint disease due to the degradation of the joints, the articular cartilages and subchondral bone. It is caused by the mechanical stress to the joints and produces the symptoms like joint pain, swelling, stiffness etc. Eventhough the disease effects any joint in the body, most commonly involved joints are major joints and weight bearing joints of the body like hip and knee joint. Due to the life style, Indians suffers from knee 
joint osteoarthritis where as western country suffers from hip joint osteoarthritis commonly.

The incidence of this disease increases with the age and the prevalence is more in females $(25 \%)$ when compared to the males (16\%). (1http://en.wikipedia.org/wiki/Osteoarthritis) . Almost all persons by Age 40 have some pathologic change in weight bearing joint. The reported prevalence of Osteoarthritis from a study in rural India is $5.78 \%$. Obesity, Occupational knee bending, Physical labour etc., are some of the predisposing factors for the disease. (2) It has become one of the major causes for the knee replacement surgeries.

Hence an attempt has been made to critically analyze the aetio-pathogenesis of the disease and the drugs that are useful for the management of the disease osteoarthritis.

\section{Aims and objectives:}

To analyze the panchalakshana nidana of the sandhigata vata and the aetio-pathogenesis of the osteoarthritis.

To analyze the drugs useful for the management of the disease.

\section{Materials and methods:}

As the study is a review study, the available literature like the samhitas and other books are searched for the disease and all the relevant content is considered and analyzed to get a comprehensive concept in the management of the osteoarthritis.

\section{Observations: \\ Etiology:}

Ruksha, Laghu, Sheeta, Katu ahara and vihara like Ati Vyayama, Langhana, Abhighata. In Manasika like Chinta,
Shoka, Bhaya are the causative factors of the disease.

In Kalaja factors, Shishira and Greeshma ritu are the major seasons where the patients get affected or have the increased incidence of the disease.

Other factors like weakness during diseased state (Rogatikarshana) and injury to the marma sthanas (Marmaghata), emaciation (Dhatu Kshaya) etc are considered as the causative factors for osteoarthritis, Margavorodha are comes under Vishesha Nidana

\section{Clinical features:}

The disease may not show any poorvaroopa. But the clinical signs and symptoms include joint pain (Sandhi vedana, Sandhi Shotha), Vatapoorna druti sparsha, pain and tenderness during the movements of the joints (Prasarana akunchana pravruthi savedana), crakling sounds (Atopa) and degeneration of the joint (Hanti sandhi).

\section{Samprapti Ghatakas:}

- Nidana: Vata Prakopaka

Nidana

- Dosha: Vata esp. Vyanavayu, Shleshaka Kapha

- Dushya: Asthi, Majja, Meda

- Srotas: Asthivaha, Majjavaha and / or Medovaha

- Srotodusti : Sanga

- Agni: Mandagni

- Dosha Marga: Marmasthi Sandhi

- Roga Marga: Madhyam

- Udbhavasthana : Pakvashaya

- Vyaktasthana: Asthi-Sandhi

\section{Prognosis:}

Sandhigatavata is one of the Vatavyadhi, therefore it is Kastasadhya because it occurs in aged people and is situated in Marma sthana, It is Madhyama roga marga, And it is Asthi, and Majja Dhatu Ashrita. 


\section{Probable Pathogenesis:}

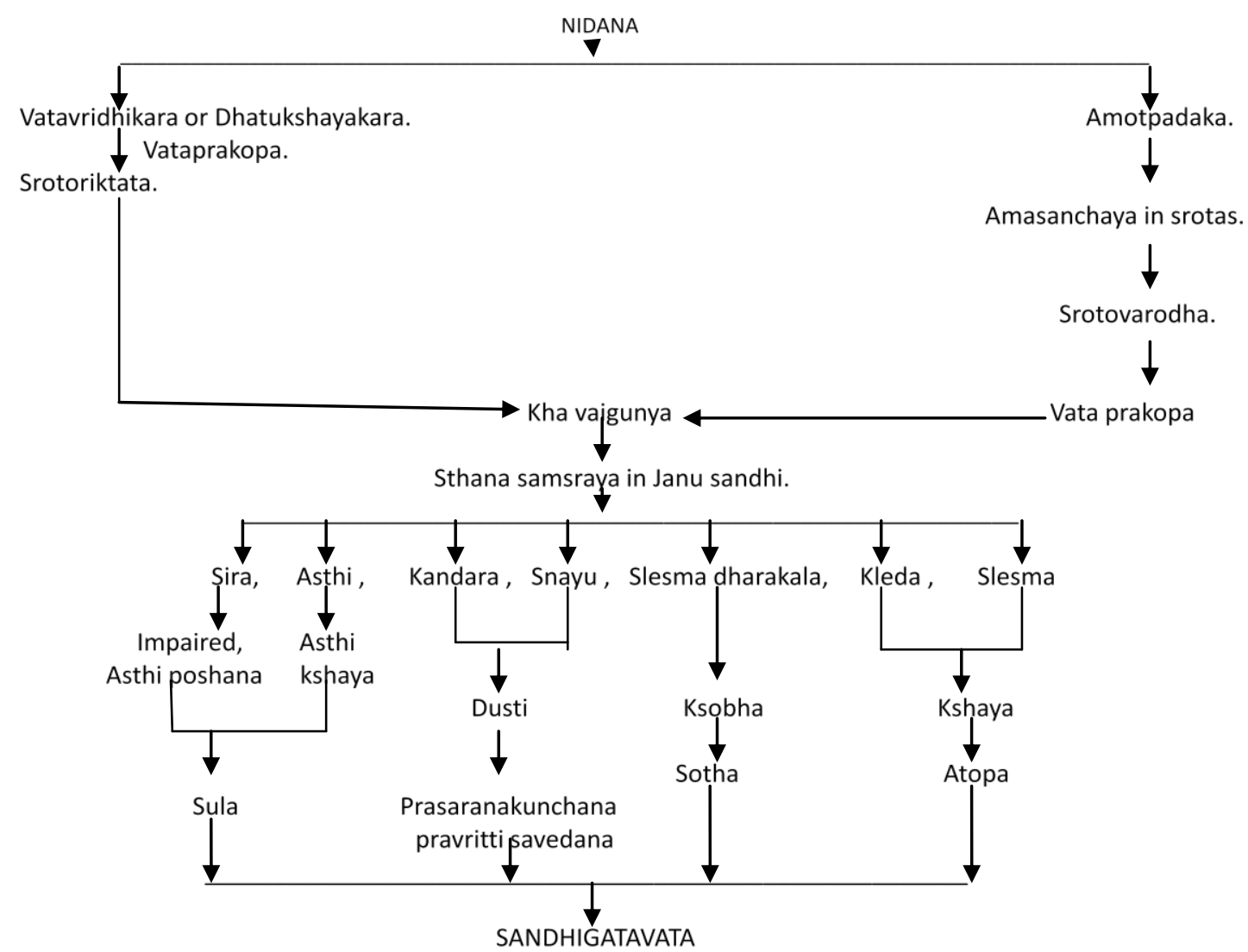

Differential Diagnosis:

\begin{tabular}{|c|c|c|c|c|}
\hline Factors & $\begin{array}{l}\text { Jaanu } \\
\text { Sandhigata vata }\end{array}$ & Amavata & Vatarakta & Koshtrukashirsha \\
\hline Amapradhanya & Absent & Present & Absent & Absent \\
\hline Jvara & Absent & Present & Absent & Absent \\
\hline Hridgaurava & Absent & Present & Absent & Absent \\
\hline Prone age & Old Age & Any age & - & - \\
\hline Vedana & $\begin{array}{l}\text { At Prasarana } \\
\text { Akunchana } \\
\text { Pravritti }\end{array}$ & $\begin{array}{l}\text { Vrischik Dansha } \\
\text { Vata and } \\
\text { Sanchari }\end{array}$ & $\begin{array}{l}\text { Mushika } \\
\text { Damshavat } \\
\text { Vedana }\end{array}$ & Tivra \\
\hline Shotha & $\begin{array}{l}\text { Vatapurna Driti } \\
\text { sparsha }\end{array}$ & $\begin{array}{l}\text { Sarvang and } \\
\text { Sandhigata }\end{array}$ & Mandala yukta & $\begin{array}{l}\text { Koshtruka } \\
\text { Shirshvat }\end{array}$ \\
\hline Sandhi & $\begin{array}{l}\text { Weight bearing } \\
\text { Joint (Knee Jt.) }\end{array}$ & $\begin{array}{l}\text { Starts from small } \\
\text { Jt.later effects big } \\
\text { Sandhi }\end{array}$ & $\begin{array}{l}\text { Small } \\
\text { Sandhi }\end{array}$ & Only Jaanu \\
\hline Upashaya & Abyanga & Ruksha Svedana & $\begin{array}{l}\text { Rakta } \\
\text { Shodhana }\end{array}$ & Rakta Shodhana \\
\hline
\end{tabular}




\section{Treatment:}

In Ayurveda, the treatment of sandhigatavata is aimed at reducing the Vata dosha and to increase the shleshaka kapha so that the joint spaces are adequately lubricated for the free movement of the joints. For this many procedures have been mentioned like snehana, swedana, Mridu Samshodhana, Basti and Vatahara Aushadha, Ahara and Vihara.

In some case practices like upanaha, agnikarma, bandhana, mardhana etc are also described.

Sandhigata Vata may be correlated with degenerative joint disease or Osteoarthritis, which in turn cripples the patient to the maximum, extends and reduces the total working capacity of the person.

In the modern system of medicine, the treatment adopted for the osteoarthritis includes administration of antiinflammatory drugs, analgesics for the pain relief. In much extreme cases some surgical procedures like joint replacements are also adopted.

\section{Drugs that proved clinically effective in osteoarthritis:}

There are so many drugs are mentioned in Ayurveda which are said to be having vata hara property and are useful for the treatment of the all types of the Vata disorders. But a few drugs are typically useful for the treatment of the joint disorders. They are as follows:

\section{Nirgundi (Vitex negundo L. - Verbenaceae):}

Vishnu dharmasutra quotes Nirgundi. The term Shephalika and Nirgundi for most of the times. Karma is VataKapha hara, Caksushya, Keshya, Krimigna, Vrunaropana. Upayokta are Gandamala, Kasa Swasa, Vatavyadhi. Researches are Anticancer, Antimicrobial, Anti-inflammatory, Hepatoprotectivity. (22)

\section{Eranda (Ricinus communis L. - Euphorbiaceae)}

In guna it is Snigdha, Tiksna, Suksma, karma are Rechana, Vrishya. Upayokta are Pliharoga,Udavarta, Vastishoola, Gulma, Antravruddhi, Katishoola, Vatarakta. Kasa. Researches are Anti-inflammatory, Hepatoprotective, Anticholestatic activity. $(22,23)$

\section{Koranta (Barleria prionitis L. - Acanthaceae)}

Rasa is Tikta, Madhura, Guna is Laghu,Virya is Ushna, Vipaka is Madhura. Doshaghnata is Kapha,Vata hara, Karma is Keshyaranjaniya,Vedanashamaka. Chemical constituents are Barlerin, Acetyle barlerin, Scutellarein, Neophesperidoside

Research work said CNS depressant activity in mice.(24)

\section{Bala (Sida cordifolia L. - Malvaceae) \\ Bhavamishra mentioned four} varities those are Bala, Atibala, Nagabala, Mahabala. Researches are it effects as Sedative. Rasa is Madhura,Gunas are Laghu, Snigdha, Pischila. Virya is Sheeta, Vipaka is Madhura, Doshaghnata are VataPittahara, Karma are Balya, Brumhana, etc. Chemical constituents are Ephedrine, hypaphorine, vasicinone, vascicine, vasicinol, choline, betaine, phytosterol etc. Research works are sedative effect and Significant potentiating of phenobarabitone sleeping time in mice. (22)

\section{Vishwa (Zingiber officinale Roscoe. - Zingiberaceae)}

- It is observed that Shunti is considered as Vibandhahara (alleviates constipation) but at the same time it is also indicated for Atisara. Here it is important to identify that the former indication is for Shunti when it is given in the powder form without Anupana, the later property is exhibited when administered along with 
Takra. Rasa is Katu, Guna are Guru,Ruksha,Teekshna, Virya is Ushna, Vipaka is Madhura, Doshaghnata are Kapha Shamaka, Karma are Vata Kapha hara, Deepana and Bhedana. Chemical constituents are Gingirol, Alpha and Beta Zingiberenes, Zingirone, Alpha curcumene, citronellol.,etc. Research work said that Anti-inflammatory and antiarthritic activity. It has shown marked antiinflammatory activity in rats which is comparable to prednisolone. $(22,25)$

\section{Discussion:}

Sandhigatavata causative factors like Aharaja, Viharaj, Manasa and other Vata Prakopaka Nidanas are mentioned in detailed for the occurrence of Vatavyadhi. Though Sandhigatavata specially occurs in Vriddhavastha which is Pariharanikala in which Dhatukshaya takes place which leads Vataprakopa. Vata and Asthi have Ashraya-Ashrayi Sambandha. That means Vata is Situated in Asthi. In Vriddha kala increased Vata diminishes Sneha from Asthidhatu by its opposite qualities to Sneha. Due to diminution of Sneha, Khavaigunya (Rikta Srotas) occurs in Asthi which is responsible for the production of Sandhigatavata.

In the Samprapti of Sandhigatavata, Prakupita Vata gets situated in Asthi Sandhi where Khavaigunya - Rikta Srotas is already present. Then Dosha Dushya Sammucchana takes place in Asthi Sandhi and further in Samprapti, the disease Sandhigatavata appears with its symptoms. Sandhigatavata is Kastasadhya vyadhi because all the Vatavyadhis are difficult to cure and they are said as Mahagada. So being a Vatavyadhi, Sandhigatavata is Kastasadhya. Madhyama Rogamarga, Situation in Marma Asthi Sandhi, Vitiation of Asthi and Majja, Dhatukshya, Vriddhavastha also makes it Kastasadhya.

Symptoms of Sandhigatavata are Sandhishula, Sandhishotha, Akunchana
Prasarana Janya Vedana and Hanti Sandhi Gati described by various Acharya. Here Sandhishula and Sandhishotha occur due to Vataprakopa. A special type of Shotha i.e. Vatapurna driti Sparsha or Atopa is mentioned which indicates Vata dominancy of Shotha. Akunchana Prasaranjanya Vedana and Hanti Sandhi Gati occur due to Kaphakshaya and Vata Prakopa.

Symptoms of Osteoarthritis are similar as of Sandhigatavata i.e. Joint pain, Swelling, Stiffness Disability and Crepitations over joint. Osteoarthritis is the most common form of arthritis. It is a degenerative type of arthritis which mainly occurs in old age. Degeneration takes place in the joint which makes the individual disabled or handicapped. Degeneration occurs continuously in most of the patients which makes the person disabled for the lifelong. It is a chronic degenerative disorder of multifactorial etiology characterized by loss of articular cartilage and periarticular bone remodeling. It involves the entire joint including the nearby muscles, underlying bone, ligament, synovium and capsule. The risk factors for osteoarthritis are old age, obesity, female sex, major joint trauma, repetitive stress, genetic factors, prior inflammatory joint diseases and metabolic or endocrine disorders.

In Allopathic science, the scientists believe that once the disease Osteoarthritis has taken place, then it is very difficult to reverse or block that disease process. Till date, no treatment is available that can reverse or slow or block the disease process. Allopathy science has only palliative treatment for Osteoarthritis. The following group of drugs help in reducing the pain and swelling.

- Analgesics - to provide relief in pain.

- Anti inflammatory drugs - to get relief in swelling.

- Anti oxidants e.g. vitamin A,B,C,E, etc. - to prevent the joint from 
oxidative damage. Antioxidants nourish all the tissues.

- Weight reduction - Osteoarthritis mainly occurs in weight bearing joints. Obesity is a risk factor for Osteoarthritis. Excess weight gives burden to the joint and that leads joint damage. 11 pound weight reduction cuts $50 \%$ risk for Osteoarthritis. 5\% weight loss in over weight patients gives $18 \%$ gain in overall function. So weight reduction is very essential for the treatment of Osteoarthritis.

Acharya Charaka has mentioned repeated use of Snehana, Svedana Basti and Mrudu Virechana for the treatment of Vatavyadhi. He has not mentioned the Treatment of Sandhigatavata separately. Acharya Sushruta has described specific treatment for the Sandhigatavata first time i.e. Snehana, Upanaha, Agnikarma, Bandhana and Unmardana,

According to Ayurveda, treatment is 'Vighatana of Samprapti', so the treatment of Sandhigatavata aims are:

- Agnisamata - Because Ayurveda believes Mandagni is responsible for the production of all the diseases. In Sandhigatavata Vriddhavasta leads Agnivaishamya and same Agnivaishamya leads Vataprakopa. So to achieve Agnisamata is very essential for the Shamana of the diseases.

- Vatashamana - As like Agni, Vayu is responsible for the production of any disease. Sandhigatavata is a type of Vatavyadhi which occurs due to Vataprakopa. So for the Shamana of Sandhigatavata, treatment should be like that which can do Vatashamana.

- Kaphavriddhi (Increase Snigdha guna) - In Sandhigatavata, Rikta srotas is in Asthi Sandhi. That means diminution of Snehadi Guna in AsthiSandhi occurs which provides place to Vata to get situated there and so the disease Sandhigatavata produces. By treatment Rikta srotas is filled by
Sneha. Thus Khavaigunya is corrected and so Shamana of Sandhigatavata is achieved. Here Vatashamana and correction of Khavaigunya is achieved by treatment.

- Rasayana - Sandhigatavata specially occurs in Vriddhavastha due to Dhatukshya. A Rasayana drug nourishes Dhatus and overcomes Dhatukshaya. So it should be in for the treatment of Sandhigatavata.

\section{Make surrounding tissue strong -}

Muscles, ligaments and tendons are responsible for the joint stability. So surrounding tissue of the joint must be strong to prevent or cure the Osteoarthritis. If they are weak, joint damage will occur soon even with the minimal load. Treatment of osteoarthritis should be like that, which makes tissue strong. In Ayurveda, Sandhishula is one of the symptom of Mamsakshaya and Sandhisphutana is a symptom of Majjakshaya.

\section{Provide materials which are required for healthy bone structure \\ Weak bone can't bear even normal} load and it immediately gets damaged. So bone must be healthy and treatment should be like that only.

\section{Samprapti Vighatana Anusara}

Here, due to causitive factors Vata gets aggravated that locates and afflicts

The jaanu sandhi. As earlier drugs are having Vata shaman properties. So it decreases the aggravated vata and prevents the affliction of jaanu sandhi.

The drugs mentioned in the article like Nirgundi, Eranda, Bala, etc are having excellent vatahara property and they act as rasayana, balya and kapha vardhaka and help to reduce the vata. Thus the drugs can be effectively used for the treatment of the disease. 


\section{Conclusion}

Thus from the above it can be concluded that sandhigatavata is one of the disease which causes crippling to the patients and the drugs like Nirgundi, ect chelp in the management of the disease.

\section{References}

1. Dev Radhakant. Shabdha Kalpa Dhruma.Nag Publisher New Delhi. New Gian offset Printers. New Delhi. 1987. Vol. - 5. 240.p.p.

2. Tripathy Bramhanand. Charaka Samhita. Choukamba Surbharati Prakashan, Varanasi. 2005. Chikista sthana. $28^{\text {th }}$ Chapt. 955.p.p.

3. Yadavaji T.A. Charaka Samhita (Revised by Charaka and Dridhabala with the Ayurvedadipika commentary of Chakrapanidatta) Choukamba Surbharati Prakashan, Varanasi. 2001. $4^{\text {th }}$ Edition. Chikista sthana. $28^{\text {th }}$ Chapt. 105.p.p.

4. Shastri Kaviraj Ambikadutta. Shushruta Samhita. Purvardha. Chukumba Sanskrit Samsthana Publisher, Varanasi. 2007. $9^{\text {th }}$ Edition. $1^{\text {st }}$ Chapt. Nidana Sthana. 228 to 236 p.p.

5. Paradker Harisadashiv. Astanga Hridaya. Choukamba Orientalia, Varanasi. 2007. Vol.- $2^{\text {nd }}$.

6. Sharma Shivprasad. Asthanga Sangraha of Vrudha Vaghbhata (Sheshilekha vyakhya samvalit). Choukamba Sanskrit Serieas, Varanasi. 2006. $1^{\text {st }}$ Edition. Nidana sthana. $15^{\text {th }}$ Chapt. 414.p.p.

7. Krishnamurty K.R.. Asthanga Sangraha. Choukamba Sanskrit Serieas, Varanasi. 2005. $5^{\text {th }}$ Edition. Nidana sthana. 242 - 245.p.p.

8. Shasthri Sudarshan and Upadhyaya Yaadunandana.Madhav Nidana. Chukamba Bharati Academy Publishers. 2009. $1^{\text {st }}$ Edition. Part-1. $22^{\text {nd }}$ Chapt. 463.p.p.

9. Krishnamurthy K.R.. Sharangadhara Samhita. Choukamba Orientalia,
Varanasi.2001.4 ${ }^{\text {th }}$ Edition. $7^{\text {th }}$ Chapt. 40-41.p.p.

10. Mishra Bramhashankara. Bhava Mishra Praneeta Vidhyotini teeka. Choukamba Sanskrit Serieas, Varanasi. 2005. $9^{\text {th }}$ Edition. Part $2^{\text {nd }}$. Vatavyadhi vikara. 264 - 265.p.p.

11. Srikanttha murthy K.R. Bhavaprakasha of Bhavamishra. Chukumba Sanskrit Samsthana Publisher, Varanasi. 2004. Vol $-1^{\text {st }} \cdot 245 . p . p$.

12. Tiwari Premvati. Kashyapa Samhita. Choukamba Vishwabharati Oriental Publishers, Varanasi. 2002. $1^{\text {st }}$ Edition. Sutra, Khila Sthana. 23, 40, 68,637.P.P.

13. Shasthri Lakshmipati. Yogaratnakara. Chukumba Sanskrit Samsthana Publisher, Varanasi. 2004. $8^{\text {th }}$. Edition. Vatavyadhi chikitsa prakarana. 517.p.p.

14. Tripathi Jagadeshwerprasad. Chakradutta. Chukumba Sanskrit Samsthana Publisher, Varanasi. 1983. $5^{\text {th }}$. Edition. 22 $2^{\text {nd }}$. Chapt. $181-$ 214.p.p.

15. K.H.Krishnamurthy and Sharma Priyavat. Bhela Samhita. Choukamba Vishwabharati Oriental Publishers, Varanasi. 2008. $1^{\text {st }}$ Edition.Chikitsa sthana. $23^{\text {rd }}$ Chapt. 455-457.p.p.

16. Tripathi Hariprasad. Harita Samhita. Choukamba Vishwabharati Oriental Publishers. 2004. $1^{\text {st }}$ Edition. 20 ${ }^{\text {th }}$ Chapt. 343. P.p.

17. Ojha Jharkhande and Mishra Umapati. Dhanvantari Nighantu. Choukamba Vishwabharati Oriental Publishers Varanasi. 1996. $2^{\text {nd }}$ Edtion. 86 ${ }^{\text {th }}$ Chapt. 87.p.p.

18. Sharma Priyavat. Dravya Guna Vignyana. Choukamba Vishwabharati Oriental Publishers Varanasi. 2005.1 ${ }^{\text {st }}$ Edition. Part $2^{\text {nd }}$. 66.p.p.

19. Sharma Priyavat and Sharma Guruprasad. Kaidev Nighantu. Choukamba Vishwabharati Oriental Publishers Varanasi. 1979.1 ${ }^{\text {st }}$ Edition. Oushadhi varga. 26.p.p. 
20. Shasthri Ambikadutta. Bhaishajya Ratnavali. Choukamba Vishwabharati Oriental Publishers Varanasi. 2004. $17^{\text {th }}$ Edition. 308,584,580,606,769.p.p.

21. Tripathi Indradev. Raj Nighantu. Choukamba Vishwabharati Oriental Publishers Varanasi. 2003. $3^{\text {rd }}$ Edition. Shatahadi varga. 80.p.p.

22. Nirmal $P$ et.al, Influence of six medicinal herbs on collagenaseinduced osteoarthritis in rats. Am J Chin Med. 2013;41(6):1407-25.

23. Medhi B, Kishore K, Singh U, Seth SD. Comparative clinical trial of castor oil and diclofenac sodium in patients with osteoarthritis.Phytother Res. 2009 Oct;23(10):1469-73. doi: 10.1002/ptr.2804.

24. Singh B et.al., Anti-inflammatory activity of 'TAF' an active fraction from the plant Barleria prionitis Linn.J Ethnopharmacol. 2003 Apr;85(23):187-93.

25. Paramdeep G.Efficacy and tolerability of ginger (Zingiber officinale) in patients of osteoarthritis of knee.Indian J Physiol Pharmacol. 2013 AprJun;57(2):177-83. 